\title{
時間信頼性と連結信頼性を統合した道路評価法 の開発および金沢市道路ネットワークへの適用
}

\author{
土倉 悟 1 中山 晶一朗 2 - 高山 純一3 \\ 1学生員 金沢大学大学院自然科学研究科（干920-1192 石川県金沢市角間町） \\ E-mail:kabuku@stu.kanazawa-u.ac.jp \\ 2正会員 金沢大学准教授 理工研究域環境デザイン学系（†920-1192 石川県金沢市角間町） \\ E-mail: snakayama@t.kanazawa-u.ac.jp \\ 3フェロー会員 金沢大学教授 理工研究域環境デザイン学系（†920-1192 石川県金沢市角間町） \\ E-mail: takayama@t.kanazawa-u.ac.jp
}

\begin{abstract}
道路ネットワークのサービスの評価において，道路ネットワークの信頼性についての評価の重要性が高 まっている。しかし，信頼性の概念は様々なものがあり，それらをまとめて評価することはこれまであま り実施されてこなかった．本研究では道路の信頼性として代表的な時間信頼性と連結信頼性を取り上げる. そして，それら時間信頼性と連結信頼性を統合した期待総旅行コストを定義し，時間信頼性と連結信頼性

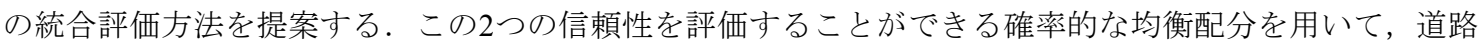
ネットワークのリンク追加による便益向上を評価する方法を構築する．さらに，金沢市道路ネットワーク に適用することで構筑した統合評価法や配分モデルの利用可能性などを考察する.
\end{abstract}

Key Words : travel time reliability, connectivity reliability, stochastic user equilibrium

\section{1. はじめに}

近年，経済・社会活動の高度化とともに道路ネットワ 一クのサービスの向上だけではなく, サービスの安定提 供も求められるようになった. 道路ネットワークのサー ビスには様々なものがあると思われるが，時間通りに目 的地に到着できるかやOD間で移動可能な道路リンクが どれだけあるかなどは特に重要であると考えられる.

道路の信頼性については様々な考え方があるが，中 山'は，それを連結信頼性，時間信頼性，走行信頼性の3 つに分類している. 本研究では, 連結信頼性と時間信頼 性の $2 つ に$ 着目する。 道路ネットワークの信頼性を評価 のためには，連結信頼性と時間信頼性の評価指標が必要 になる.

時間信頼性について，その指標としては旅行時間の分 散・標準偏差・変動係数を用いることができる. しかし, 旅行時間の分散や標準偏差は直感的にはどれほどのばら つきかが把握しにくく, 利用者に提供する際に理解され にくいという問題がある，そこで，時間信頼性の統計指 標として\%タイル值 (パーセンタイル值) がよく用いら れている％％タイル值を用いて計算されるバッファータ イム（Buffer Time: BT）やそれに類するものが代表的な
ものと言える.

連結信頼性の指標についての研究としては, 構造関 数芑を定義し，ノード間の連結確率として指標化してい るものが非常に多い. 連結確率の算出方法としては, 若 林・飯田 ${ }^{3}$ は最少パス法と最少カット法を用いた. 最少 パス法とは，ノード間を結ぶ全てのパス（経路）が同時 に通過できなくなることはない確率を求める方法である. 最少カット法とは，ノード間においてリンク途絶が発生 すると通過できなくなるとき, リンク途絶が最小数とな るリンクのカット集合を求めて発生する確率を求める方 法である. また, 何通りの経路で移動できるのかという ことを評価するために瀬戸ら ${ }^{4}$ は全ODペアに非重複経路 が最低N本存在するというN-edge-connected networkを用い ている. 同様の概念に沉長性というものがあり, 各リン クの途絶に着目して他の途絶条件付き連結確率の情報工 ントロピーとしてのて長性指標が提案されている5 .

中山11, のに整理してあるように，これまでの研究で時 間信頼性や連結信頼性に着目したものは非常に多くある. しかしながら, 道路ネットワークの評価のためには, 連 結信頼性と時間信頼性という道路の信頼性だけでなく, 通常の費用便益評価の3便益を含めて，それらを統合し て評価する必要がある，連結信頼性や時間信頼性につい 
て，それぞれ単独の研究は極めて多いが，連結・時間信 頼性を統合的に扱う研究は非常に少ない，そこで，本研 究では，時間信頼性と連結信頼性を統合した道路ネット ワークの評価方法を開発し，金沢市道路ネットワークに 適用させ，金沢市の山側環状道路の整備便益を連結・時 間信頼性を含めて算出し，開発した統合評価法の利用可 能性などを評価する.

\section{2. 道路ネットワークの信頼性}

本章では，時間信頼性と連結信頼性のそれぞれについ ての評価方法を述べる.

\section{（1）時間信頼性}

時間信頼性の指標は様々であるが，前章で述べたよう に本研究では多くの人々にとって分かりや寸い\%タイル 值を用いることにする％\%タイル值は道路の時間信頼性 を評価する際によく利用される指標である。その中でも 95\%タイル值が最もよく用いられている. 何パーセント タイル值にすべきかは状況・場所など様々な要因によっ て異なると思われ, 詳細な調査が必要であろう. 本研究 では，何パーセンタイル值を用いるべきかという問題は 対象とせず，時間信頼性指標として何パーセントタイル 值がよいのかが判明している状況下での連結・時間信頼 性の統合評価方法を提案する. 便宜的に, 最もよく用い られる 95\%タイル值によって時間信頼性を評価できる と仮定する. なお，別のパーセンタイル值を用いること になったとしても, 以降の議論には全く影響しない.

95\%タイル值（= $t_{85} ）$ とは, ある確率変数 $x か ゙ ~ 95 \%$ の確率で $X \leq t_{\bar{q}}$ になる值のことを指寸．利用者は旅行 時間の期待值ではなく $95 \%$ タイル值を考慮して行動す るとする。逆に言えば，このような利用者は残り $5 \%$ の 確率で想定していた時間（ $\left.t_{98}\right)$ より遅れることを覚悟 の上で行動していることになる.つまり $95 \%$ の確率で 間に合い，5\%の確率で遅刻するような行動を想定する。

リンク旅行時間の\%タイル值については, リンク交通 量の\%タイル值を旅行時間関数に代入することで算出で きる. 一方で, 評価に必要な経路旅行時間の\%タイル值 については, 経路旅行時間はリンク旅行時間の和であり, 各リンクの旅行時間や交通量には相関があるため，その 経路を構成するすべてのリンクの旅行時間の同時確率密 度関数などが分からないと計算ができない，隣り合った

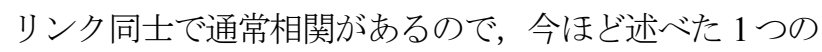
リンクの場合のように, 各リンクの交通量の\%タイル值 がわかるだけでは計算できない.

そこで, 本研究では, 近似的に経路旅行時間の\%タイ ル值を計算する方法を用いる. 計算方法自体は今村ら》 と同じであるため，ここでは概略を説明するのみとする．
各リンクの交通量の分布は後述する配分モデルから導出 でき，それを用いる．配分モデルから計算する各リンク の平均と分散・共分散から, 経路旅行時間の平均と分散 は計算可能である. 本研究では, 中山ら ${ }^{8)}$ ・ 今村ら ${ }^{7} に$ 従い，交通量は正規分布とするが，例え交通量が正規分 布であったとしても一般に旅行時間は正規分布に従うと は限らず，どのような分布に従うかは旅行時間関数に依 存して決まる. そして, リンク旅行時間の分布形とその 和である経路旅行時間の分布形とも同じとは限らない. 本研究では，このような経路の旅行時間分布を正規分布 もしくは対数正規分布と近似してその\%タイル值を計算 する.

\section{a) 正規分布 1}

旅行時間の期待值と分散の算出式はそれぞれ式(1), 式(2)の通りである.

$$
\begin{gathered}
E[T]=t_{0}\left\{1+\frac{E\left[X^{2}\right]}{C^{2}}\right\} \\
\operatorname{Var}[T]=E\left[T^{2}\right]-(E[T])^{2}
\end{gathered}
$$

ここで， $X$ はリンク交通量の確率変数， $T$ はリンク旅行 時間の確率変数, $E[\cdot]$ と $\operatorname{Var}[\cdot]$ はそれぞれ平均と分散を計 算する演算子である. 旅行時間は BPR 関数を用いて計 算する. パラメータについては $\alpha=1.0, \beta=2.0$ とする.

3 章で詳述するが，交通量は正規分布と仮定する. そ の場合の近似的な経路旅行時間分布は正規分布と寸る.

後述する配分モデルにおいて（その分布形はわからない ものの），経路旅行時間の平均と分散は計算可能である ため, ここでは経路旅行時間分布は配分モデルによって 計算された平均と分散を持つ正規分布と近似する. 経路 旅行時間を正規分布と仮定すると，その $95 \%$ タイル值 は標準正規分布表から式(3)で算出できる.

$$
c_{95}=1.645 \sqrt{\operatorname{Var}[C]}+E[C]
$$

ここで，C $c_{95}$ は経路旅行時間の $95 \%$ タイル值，C は経路 旅行時間の確率変数である.

\section{b) 正規分布 2}

ここで，前節で述べたものと別の経路旅行時間分布の 近似を考えよう。

経路旅行時間分布の近似を考えるために, $c_{k}^{r s}($.$) は$ $\mathrm{OD}$ ペア $r s$ の経路 $k$ の旅行時間を算出する関数, $\mathbf{X}$ はリ ンク交通量の確率変数ベクトル（全てのリンク交通量の 確率変数を要素に持つ) とすると, $c_{k}^{r s}(\mathbf{X})$ はその経路 の旅行時間の確率変数となる. 経路旅行時間関数を以下 の式のように交通量の平均值 $(E[\mathbf{X}])$ 周りに一次のテイ ラー展開をする.

$$
c_{k}^{r s}(\mathbf{X}) \approx c_{k}^{r s}(E[\mathbf{X}])+\left.\nabla_{\mathbf{x}} c_{k}^{r s}(\mathbf{x})\right|_{\mathbf{x}=E[\mathbf{X}]}(\mathbf{X}-E[\mathbf{X}])
$$

ここで，x はリンク交通量（の実現值）のベクトルであ 
る. なお, $c_{k}^{r s}(E[\mathbf{X}])$ は交通量がその平均值である時の 経路旅行時間, $\left.\nabla_{\mathbf{x}} c_{k}^{r s}(\mathbf{x})\right|_{\mathbf{x}=E[\mathbf{X}]}$ は交通量がその平均值で ある時の経路旅行時間の勾配であり, ともに確定值もし くは確定値ベクトルである.

リンク交通量が正規分布に従うと仮定しているため, また，正規乱数の和も正規乱数となるため，上の式によ って与えられる経路旅行時間も正規分布に従うことにな る. 上の式によって与えられる経路旅行時間の近似的な 正規分布から経路旅行時間の $95 \%$ タイル值を計算するこ とができる.

\section{c) 対数正規分布}

正規分布は取り扱いが容易ではあるものの，負の值を とることがあり，また，左右対称であるため，旅行時間 としてはふさわしくない場合も考えられる. そこで, こ こでは旅行時間が以下のような対数正規分布に従うと仮 定する.

$$
\ln C \sim \mathrm{N}\left(\lambda, \zeta^{2}\right)
$$

となる.ここで

$$
\begin{gathered}
\lambda=\ln (E[C])-1 / 2 \zeta^{2} \\
\zeta^{2}=\ln \left(1+\operatorname{Var}[C] / E[C]^{2}\right)
\end{gathered}
$$

である.ただし， $\mathrm{N}\left(\lambda, \zeta^{2}\right)$ は平均が $\lambda$ ，分散が $\zeta^{2}$ の正規 分布, $E[C]$ は経路旅行時間の期待值, $\operatorname{Var}[C]$ はその分 散である. このときの旅行時間の 95\%タイル值は正規分 布の累積分布関数 $\Phi((y-\lambda) / \zeta)$ に

$$
y=\left(\ln c_{95}-\lambda\right) / \zeta
$$

を代入して

$$
\Phi(y)=0.95
$$

を解くことで求まる，最終的に旅行時間の 95\%タイル 值は

$$
c_{95}=\exp \{1.645 \zeta+\lambda\}
$$

となる.

\section{（2）連結信頼性}

連結信頼性とは, リンク機能障害が確率的に発生する としたとき, リンク障害の影響を受けずに目的地に到達 できる OD間でのトリップ確率を評価するものである.

本研究では, 平常時における道路ネットワークの信頼 度を評価する．平常時においても交通渋滞や交通事故な ぞにより，各リンクにはそれぞれ独自の信頼度を定義で きるものと考えられる，そこで，各リンクの信頼度を連 結確率と定義し, 各リンクの連結確率により OD 間の連 結確率を定義して便益算出を行うこととする.

リンクの連結確率が分かれば経路の連結確率も算出で

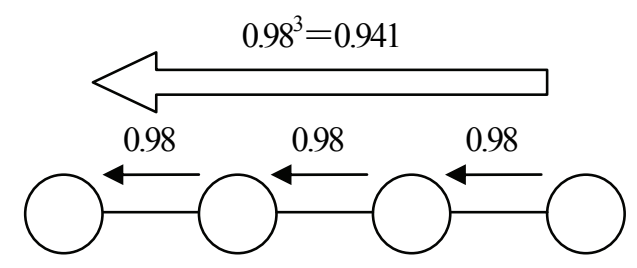

図-1 経路の連結確率の例

きる．例えば，ある経路の中に 3 つのリンクがあるとす ると，3つのリンクの連結確率が 0.98 とすると経路の連 結確率は $0.98^{3}$ となる（図-1）。より厳密に OD 間の連結 確率を算出するためには, 最少パス法や最少カット法を 用いるのが的確かと思われるが, 計算の簡略化として, 各 OD の連結確率を各 $\mathrm{OD}$ 間の最小旅行時間となる経路 の連結確率とする.

\section{3. 需要変動下での確率的利用者均衡配分モデル}

本研究では, 交通需要が確率的に変動すること, リン クが確率的に途絶寸ることの $2 つ の$ 確率要因を考える. 利用者は交通需要を事前に確実には知ることができず, 利用者は交通需要を確率事象であると捉えていることと する. 一方，リンクの途絶は確率的に発生するものでは あるもののそれは比較的長期の事象であることが多く, その情報は比較的容易に入手できることとして，事前に その途絶を利用者は把握しているとする. 地震等で道路 は途絶するが，どの箇所が途絶しているのかを利用者は トリップ直前には知っていると仮定する. リンク途絶は 常に起こっているわけではなく, 確率的に発生する.リ ンク途絶は確率的に発生するものの, 途絶した場合, 利 用者は事前にその途絶箇所を知っているもののそこを迂 回せざるを得ず，その確率的な途絶の影響を静的に捉え るためには，例えば “平均”旅行時間がどれほど増加す るのかなどを考える必要がある.このように事前に途絶 箇所を利用者が知っているとしても分析者の視点からは リンク途絶を確率的に捉える必要がある.

リンク途絶はあらかじめ分かっているため, 通過可能 なリンクで構成された道路ネットワークについて均衡配 分モデルを考える. 上述の通り, 交通需要が確率変動す るため, その均衡配分は交通需要が確率変動するもとで の配分となる. また，リンク途絶の状態はあらかじめ利 用者はわかっているものの, 確率的に生起するために通 過可能なリンクで構成されたネットワークは様々な組み 合わせのものとなる.

一つの通行可能なリンクで構成されたネットワークに つい, 中山ら ${ }^{8)}$ ・今村られに従い, 交通需要, 寸なわち OD交通量は互いに独立な正規分布に従うと仮定する. このように正規分布の確率分布を持ったOD交通量をネ 
ットワークに配分する．本研究でもOD交通量は互いに 独立な正規分布に従うと仮定することとする.

このような配分を実際の道路ネットワークに適用する に際して, 一つの問題が生じる. 現在のところ, 確定的 なOD交通量のデータについては各種調査から得られ， それをOD交通量の平均として捉えることができる．し かし，分散については何らかのデータから算出すること は難しい場合が多い.

交通量の分散に関してはデータを得ることが一般には 困難であるが，田中ら ${ }^{9}$ は，首都高速道路のOD交通量の 平均值 $\mu$ と分散 $\sigma^{2}$ との関係について, 非線形回帰分析に より， $\sigma^{2}=16 \mu$ という関係を示した，そこで本研究では, 田中ら 9)の提案した考え方に基づき以下で示寸ように, OD交通量の分散は平均值の定数倍であると仮定する.

$\mathrm{OD} ヘ ゚ ア r s$ 間のOD交通量を確率変数 $Q^{\mathrm{s}}$ とすると，その 平均と分散はそれぞれ $\left[Q^{s}\right], \operatorname{Var}\left[Q^{s}\right]$ となる。 OD交通量 の分散は平均值の定数倍という考え方から, $\operatorname{Var}\left[Q^{5}\right]$ は $\eta E\left[Q^{s}\right]$ となる. ここで, $\eta$ は正のパラメータである.

$\mathrm{OD}$ ペア $r$ 間の経路交通量の平均を $\mu_{k}^{\prime s}$, 分散 $\left(\sigma_{k}{ }^{2}\right)^{2} を \eta \mu_{k}^{\prime s}$ と表記することとする。ODペア $r s$ 間の経路 $k$ の集合を $K^{\star s,}$ 起点ノードの集合を $R, S$ とすると, 経路交通量の分布は 以下の確率分布で示寸ことができる.

$$
F_{k}^{r s} \sim N\left[\mu_{k}^{r s}, \eta \mu_{k}^{s}\right]
$$

ここで， $F_{k}^{s}$ はODペア $r s$ 間の経路 $k$ の経路交通量の確率変 数である.

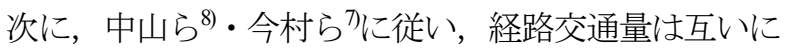
独立な正規分布に従うと仮定する。このような仮定を置 くことによって，独立な正規変数の和は正規変数になる ことから，共に正規分布に従うOD交通量と経路交通量 の関係として, 次式に示すようなフロー保存則が成立す る.

$$
\begin{aligned}
& Q^{r s}=\sum_{k \in K^{r s}} F_{k}^{r s} \quad \forall r \in R, \forall s \in S \\
& E\left[Q^{r s}\right]=\sum_{k \in K^{r s}} \mu_{k}^{r s}, \operatorname{Var}\left[Q^{r s}\right]=\sum_{\substack{k \in K^{r s} \\
\forall}}\left(\sigma_{k}^{r s}\right)^{2} \\
& \forall r \in R, \forall s \in S
\end{aligned}
$$

また，経路交通量とリンク交通量の関係としても，独 立な正規変数の和は正規変数になるため, 以下の式(14) のようにリンク $a$ の交通量の確率変数 $X_{a}$ は, 正規分布に 従う独立な経路交通量 $F_{k}^{\prime s}$ 和となり, さらに, 上述の $\eta$ を用いて式(15)のようになる.

$$
\begin{gathered}
X_{a}=\sum_{r \in R} \sum_{s \in S} \sum_{k \in K} \delta_{a, k}^{r s} F_{k}^{r s} \\
X_{a} \sim N\left[\sum_{r \in R} \sum_{s \in S} \sum_{k \in K} \delta_{a, k}^{r s} F_{k}^{r s}, \eta \sum_{r \in R} \sum_{s \in S} \sum_{k \in K} \delta_{a, k}^{r s} F_{k}^{r s}\right]
\end{gathered}
$$

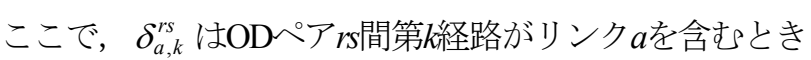
は1，そうでないときは0である。
上で述べたように経路交通量は独立であると仮定した が，リンク間では同一の経路交通量が流れるため, リン ク交通量は必ずしも独立ではない，以上の設定は，中山

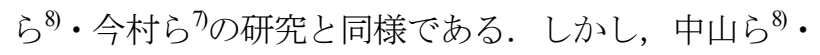
今村られでは, 最小旅行時間の経路を選択するものとな っているが，本研究では，経路を特定する必要があるた め経路選択はロジットモデルに従うとする.

$\mathrm{OD} ヘ ゚ ア r s$ 間の経路選択肢集合 $K_{s}$ から経路 $k$ が選ばれ る確率は,

$$
P_{k}^{r s}=\frac{\exp \left(-\theta c_{95, k}^{r s}\right)}{\sum_{k^{\prime} \in K_{r s}} \exp \left(-\theta c_{95, k^{\prime}}^{r s}\right)}
$$

ここで， $P_{k}^{r s}$ は ODペア $r s$ 間において経路 $k$ が選択され る確率， $c_{95, k}^{r s}$ は $\mathrm{OD}$ ペア $r s$ 間の経路 $k$ の旅行時間の 95\%タイル值，Ks $\theta:$ 分散パラメータである.

したがって, 経路交通量は以下の式で表わされる.

$$
\begin{gathered}
F_{k}^{r s} \sim N\left[\mu_{k}^{r s}, \eta \mu_{k}^{r s}\right] \\
\mu_{k}^{r s}=q^{r s} \frac{\exp \left(-\theta c_{95, k}^{r s}\right)}{\sum_{k^{\prime} \in K_{r s}} \exp \left(-\theta c_{95, k^{\prime}}^{r s}\right)}
\end{gathered}
$$

ここで, $E\left[f_{s, k}, \mathrm{O}\right] \mathrm{OD} ヘ ゚ ア r s$ 間において経路 $k$ の経路交通 量, $q^{s}$ は $\mathrm{OD} ヘ ゚ ア r s$ 間の $\mathrm{OD}$ 交通量の平均值 $\left(=E\left[Q^{5}\right]\right)$ である、

以上より，交通需要が独立な正規分布に従う場合の口 ジット型均衡配分（確率的利用者均衡配分）は，平均経 路交通量を求める以下の変分不等式問題として定式化さ れる.

Find $\boldsymbol{\mu}^{*} \in \Omega$

$$
\text { such that } \sum_{r s} \sum_{k} c_{95, k}^{r s}\left(\boldsymbol{\mu}^{*}\right) \cdot\left(\mu_{k}^{r s}-\mu_{k}^{r s^{*}}\right) \geq 0 \quad \forall \boldsymbol{\mu} \in \Omega
$$

ここで, $c_{95, k}^{r s}(\cdot)$ はODペア $r s$ 間の経路 $k$ の旅行時間の 95\%タイル值を計算する関数, $\mu_{k}^{i s}$ はODペア $r s$ 間の経路 $k$

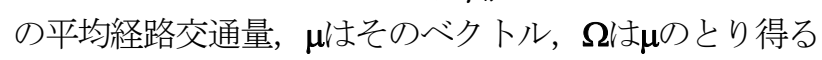
集合である. 上の問題は, 以下で示寸射影法により解く ことができる.

Step 0 : 初期許容解を求める

繰返し回数 $m:=1$, 定数 $\gamma$ と対角行列Bを設定, 初期許 容解（経路交通量パターン） $\mu^{(1)}$ を設定.

Step $1:$ 射影問題を解く 以下の射影問題を解き，その解を $\boldsymbol{\mu}^{(m+1)}$ とする.

$$
\begin{aligned}
& \min Z(\boldsymbol{\mu})=c_{95, k}^{r s}\left(\boldsymbol{\mu}^{(m)}\right) \cdot\left(\boldsymbol{\mu}-\boldsymbol{\mu}^{(m)}\right) \\
&+ \frac{1}{2 \gamma}\left(\boldsymbol{\mu}-\boldsymbol{\mu}^{(m)}\right) \cdot \mathbf{B}\left(\boldsymbol{\mu}-\boldsymbol{\mu}^{(m)}\right) \\
& \text { subject to } \forall \boldsymbol{\mu} \in \Omega
\end{aligned}
$$

ただし，・はベクトルの内積である。この問題は, Frank-Wolfe法などにより容易に解くことができる. 
Step $2:$ 収束判定

以下に示す収束条件が満たされていなければ, $m=m+1$ としてStep 1一戻る. 収束条件式がみなされていれば, 計算を終了寸る.

$$
\left\|\boldsymbol{\mu}^{(m+1)}-\boldsymbol{\mu}^{(m)}\right\| \leq \omega
$$

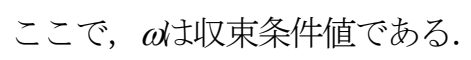

\section{4. 便益評価の式}

本研究では時間信頼性と連結信頼性を統合したコスト 算出式を定義して，それを基に環状道路整備による便益 の向上を算出する，本章ではその統合評価式につい述べ る.

ある ODについて，その OD間が連結されていれば, すなわち少なくとも 1 つ経路でその OD 間が結ばれて いればトリップを行える.しかし，全ての経路が途絶し ていれば，その OD 間でトリップを行うことができない．

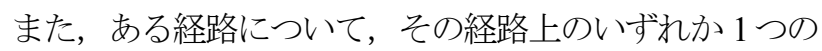
リンクが途絶してしまえばその経路でのトリップは不可 能となる. この場合, 利用者は別の経路でトリップを行 う・他機関を利用・トリップを行わないのいずれかを選 択することになる．OD 間が連結しておらず，トリップ を行うことができない場合のコストを皇する. トリッ プを行えない不利益を意味しており, 通常のトリップに 要するコストよりも大きなものと想定できる.このトリ ップキャンセルコストKを算入することで，連結信頼性 の便益評価が可能となる. トリップキャンセルコストを 含んだ期待総旅行コストの基本的な考え方は以下の式で ある。

$$
\sum_{r \in R} \sum_{s \in S} q^{r s}\left[\pi^{r s} \lambda^{r s}+\kappa\left(1-\pi^{r s}\right)\right]
$$

ここで, $q^{r s}$ は $\mathrm{OD} ヘ ゚ ア ~ r s$ 間の交通需要 (の平均值) , $\pi^{r s}$ は OD ゚゚ア $r s$ 間が連結されている確率， $\lambda^{r s}$ は $\mathrm{OD}$ ペア $r s$ 間が連結されている場合のそのコストである. 前章で交通需要は正規分布に従うとしたが，交通需要は 一般に大きなものと想定し，大数の法則からそのばらつ きは平均に比べて小さいと近似でき, 評価の際は交通需 要の実現值はその平均值のみと考えることにする．また， $\lambda^{r s}$ については，あとで詳述する，そして，この式は基 本的な考え方を段階を追って示寸ための式であり, 実際 に本研究の計算等では用いない.

2 項ロジットモデルを用いて推定する場合，トリップ を行うのか，とりやめるのか（もしくは他の交通機関を 用いるのか) の2 項ロジットモデルが考えられ, 道路利 用者の行動選択は図-2 の通りとなる。このようにして

（非連結となって）トリップができない不便益を定量的 に扱うことが可能である. トリップを行う場合のランダ

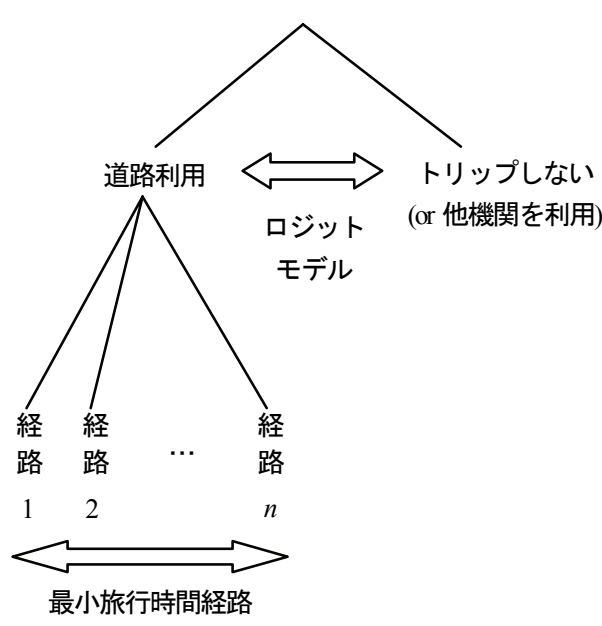

図-2 連結信頼性のための利用者選択構造

ム効用 $U^{r s}$ とトリップをとりやめる場合のランダム効 用 $\vec{U}^{r s}$ を以下のように定義する.

$$
\begin{gathered}
U^{r s}=-\theta \lambda^{r s}+\varepsilon^{r s} \\
\vec{U}^{r s}=-\rho+\vec{\varepsilon}^{r s}
\end{gathered}
$$

ここで, $\theta$ は正のパラメータ, $\rho$ は定数項, $\varepsilon_{i}, \vec{\varepsilon}^{r s}$ は ランダム項である.

トリップを取り止める場合の定数項について, $\rho=\theta \kappa$ と考えると, 2 項ロジットモデルで推定した定 数項 $\rho$ とパラメータ $\theta$ から $\rho / \theta$ として, 上述したトリ ップキャンセルコスト $\kappa$ が得られる.この推定された Кを用いることによってトリップを行えないことに対 する不便益を算定できる，なお，ここでは ODに関わら ずトリップを行えない場合の不効用は一定としているが， より複雑な設定も可能である. また, 震災時などを対象 と寸る場合, 震災直後の交通需要は通常時と大きく異な り，また，災害規模が大きくなると人命にも関わるよう な必要性の極めて高い需要も多く発生する，そのような 場合も考慮するときは状況に応じて別々に推定する必要 がある. 推定のための調查等の手法や技術開発は今後の 課題としたい.

ODペア $r s$ 間が連結されている場合はトリップを行う のか取り止めるのかの両方を選択できる. 一方で連結さ れていない場合はトリップを行わないしか選択できない. OD 間が連結している場合, その場合でもあえてトリッ プを行わないこともあり得るため，その場合の便益指標 としてのログサム変数，つまり最小コストの期待值は $-\ln \left|e^{-\theta \lambda^{r s}}+e^{-\theta \kappa}\right| \operatorname{\theta }$ として与えられる. 連結されていな い場合，その $\mathrm{OD}$ 間旅行時間は無限大と考えると最大効 用の期待值は $-\ln \left[e^{-\infty}+e^{-\theta \kappa}\right] / \theta=\kappa$ である. 連結されて いる確率が $\pi^{r s}$ であることを踏まえ，式(21)にログサム 変数を代入すると 


$$
-\frac{1}{\theta} \sum_{r \in R} \sum_{s \in S} q^{r s} \pi^{r s} \ln \left[e^{-\theta \gamma^{r s}}+e^{-\theta \kappa}\right]+\kappa \sum_{r \in R} \sum_{s \in S} q^{r s}\left(1-\pi^{r s}\right)
$$

が得られる. 2 項ロジットモデルを用いた図-2 の選択構 造を仮定する場合，式(21)より式(24)が理論的に整合が取 れている，既に述べたように，交通需要は正規分布に従 って確率変動し, 交通量・旅行時間も確率変動する。 ま た，道路利用者は，既に述べたように，経路旅行時間の 95\%タイル值を用いて行動している. したがって, トリ ップを行う場合のコストは旅行時間の $95 \%$ タイル值を 用いるべきである．前章で述べたように，式(16)のロジ ットモデルによって経路選択を行っているため, OD ペ ア rs 間が連結しており, トリップを行う場合のコスト は

$$
\lambda^{r s}=-\frac{1}{\vartheta} \ln \left[\sum_{k \in K_{r s}} e^{-\vartheta c_{95, k}^{r s}}\right]
$$

として与えることができる．ただし， $c_{95, k}^{r s}$ は ODペア $r s$ の経路 $k$ の旅行時間の $95 \%$ タイル值である.

以上をまとめると，最終的に信頼性向上便益計算のた めの総コストは以下の式になる.

$$
\begin{array}{r}
-\frac{1}{\theta} \sum_{r \in R} \sum_{s \in S} q^{r s} \pi^{r s} \ln \left[\operatorname { e x p } \left(\frac { \theta } { \vartheta } \operatorname { l n } \left[\sum_{k \in K_{r s}} e^{\left.\left.\left.-\vartheta c_{9 s, k}^{r s}\right]\right)+\exp (-\theta \kappa)\right]}\right.\right.\right. \\
+\kappa \sum_{r \in R} \sum_{s \in S} q^{r s}\left(1-\pi^{r s}\right)
\end{array}
$$

本研究では，上の式を用いて連結・時間信頼性を考慮 した総旅行コストを算出する。この総旅行コストの増減 によって交通施策の便益評価が可能となる.

\section{5. 金沢市道路ネットワークへの適用}

\section{(1) ネットワーク概要}

前章で述べた統合評価法と配分モデルを用いて，金沢 市道路ネットワークの山側環状道路建設の便益向上を算 出する.

山側環状道路に属するリンクを追加する前のネットワ 一クのノード数は 140 , リンク数は 464 である. リンク を追加した後のノード数は 149, リンク数は 494 である。 対象とするネットワークを図-3 に示す．点線のノード とリンクが追加される山側環状道路に属寸るノード，リ ンクになる.

確率的要因としては, 交通需要の確率変動とリンクの

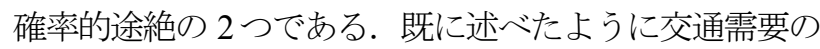
分散は平均の定数倍である. 金沢の道路ネットワークの リンク交通量の分散については，実測值より $\operatorname{Var}[X]=$ $42 E[X]$ であった. よって, 交通需要およびリンク交通量

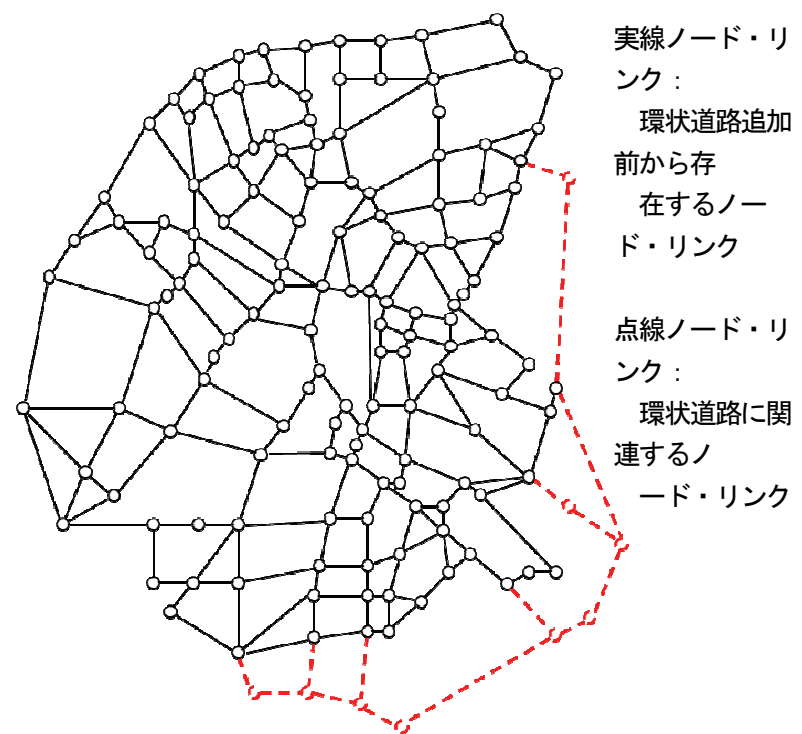

図-3 金沢市道路ネットワーク

表-1 相関係数

\begin{tabular}{|c|c|c|c|c|}
\hline \multirow{2}{*}{} & \multirow{2}{*}{ 平均 } & \multicolumn{3}{|c|}{ \%タイル值 } \\
\cline { 3 - 5 } & & 正規分布1 & 正規分布2 & 対数正規分布 \\
\hline 相関係数 & 0.8908 & 0.8941 & 0.8964 & 0.8885 \\
\hline
\end{tabular}

の分散はその平均の 42 倍とする. また, 交通需要の平 均は, 第 3 回金沢都市圈 PT 調査における平日の朝 7 時 台(7:00〜8:00)のデータを基に設定した.

本章の配分自体も平日の朝 7 時台の時間配分である. 各リンク途絶確率については 0.98 とした. リンク途絶確 率は連結信頼性等に大きく影響し，丁寧に設定する必要 があるものの，現実ネットワークの適用の際にどのよう に設定すべきは今後の課題とし, 本研究では, 時間信頼 性と連結信頼性の統合評価法を現実ネットワークでも適 用可能かどうかの検討やその評価法の特性の考察を主目 的とする．厳密な金沢ネットワークの便益評価について は，途絶確率の設定方法などの確立後に再度行いたい。 また，各 ODのトリップキャンセルコストは OD 間の最 小旅行時間の3 倍とした。

\section{(2) 配分結果の妥当性}

配分結果の妥当性を評価するために観測リンク交通量 と配分リンク交通量の相関係数を算出する. 計算結果を 表-1 に示す．計算結果より，いずれの経路旅行時間近 似法であっても相関係数はおおよそ 0.9 となり, 配分結 果はおおむ称妥当と考えられる。また，利用者が $95 \%$ タイル值を考慮して行動するとした場合の配分を比較評 価するために，平均值で評価した場合においても計算を 行った。これは確配分において旅行コストを旅行時間の 95\%タイル值ではなく，その期待值を代入して計算した ものである．ただし，配分した平均交通量での相関係数 は 0.8908 となり $95 \%$ タイル值で評価した相関係数と大 差ないという結果になった。 これは全ての人が旅行時間 の期待值を基に行動すると仮定して均衡配分する場合と 
旅行時間の 95\%タイル值を基に行動すると仮定して均 衡配分寸る場合とでは, 配分結果については大きな違い がないということを示唆しているとも考えられる．なお， 配分結果に大きな違いはないものの，平均値を用いた配 分によっては, 旅行時間の信頼性を評価することはでき ない.

\section{(3) 便益計算}

金沢市道路ネットワークにおける山側環状道路整備に よる便益算出結果を表-2, 図-4 に示寸. 結果は平均值を 用いた通常の方法では山側環状道路整備により総旅行コ ストが約 400 (万円）の減少，95\%タイル值では約 518 （万円）の減少となった．なお，これは平日の朝 7:00〜 8:00の 1 時間分での便益である.

ここで，時間信頼性と連結信頼性を考慮する場合とそ うでない場合とで便益計算結果がどの程度違うかを比較

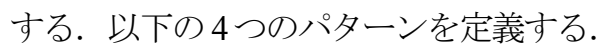

・パターン I : 時間信頼性と連結信頼性の両方を考慮し た便益計算

・パターン II : 時間信頼性のみを考慮した便益計算

・パターン III : 連結信頼性のみを考慮した便益計算

・パターン IV : 時間信頼性と連結信頼性の両方を考慮 しない便益計算（通常の方法）

時間信頼性の指標としては旅行時間を正規分布 1 に従う と仮定した場合の 95\%タイル值に統一寸る.なお，パ ターン I の結果は表-2, 図-4 の正規分布 1 の環状線と同 一の計算方法で, パターン III は表-2, 図-4 の平均値の 環状線と同一の計算方法である.

計算結果を表-3, 図-5 に示寸. 結果として，パターン Iはパターン IVの 2倍ということになった．以上のよう に, 本研究の手法を用いて, 信頼性を含めて便益計算が できることを確認することができた.

\section{6. まとめ}

本研究では，道路の信頼性として代表的な時間信頼性 と連結信頼性を取り上げ，それら時間信頼性と連結信頼 性を含めた期待総旅行コストを定義し，時間信頼性と連 結信頼性の $2 つ の$ 信頼性を統合した道路整備等の便益評 価方法を提案した．また，信頼性を評価することができ る確率的な均衡配分から得られた経路旅行時間の $95 \%$ 夕 イル值などを用いて，道路ネットワークのリンク追加に よる便益向上を評価する方法を構築した，そして，金沢 市道路ネットワークでの山側環状道路の整備によって発 生する便益の算出を時間信頼性と連結信頼性を含めて行 った. 金沢市道路ネットワークへの適用では, 観測リン ク交通量と計算平均リンク交通量との相関係数は 0.9 程 度とおおむ称良好であり，モデル適用の妥当性を確認す

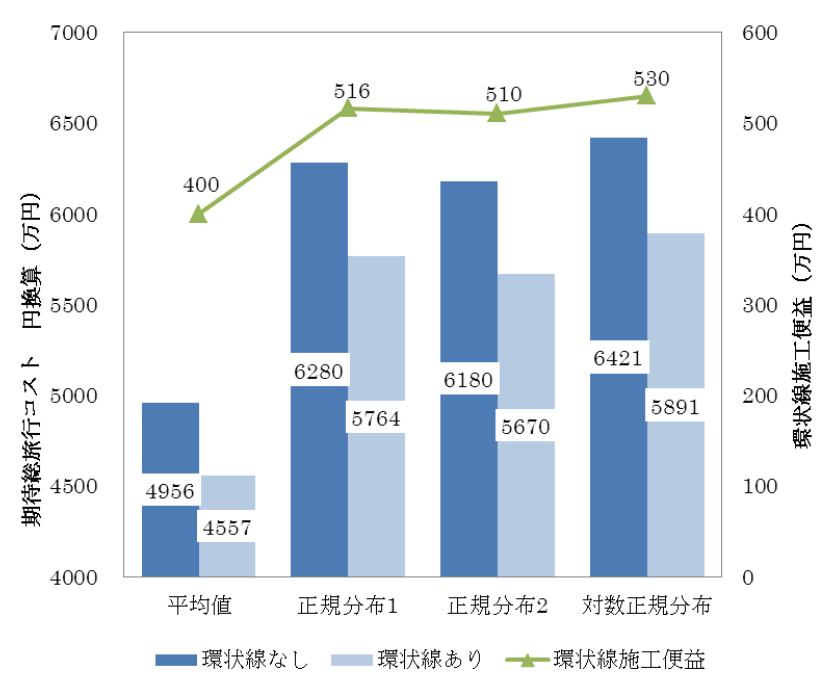

図-4＼cjkstart金沢市道路ネットワーク便益計算(万円)

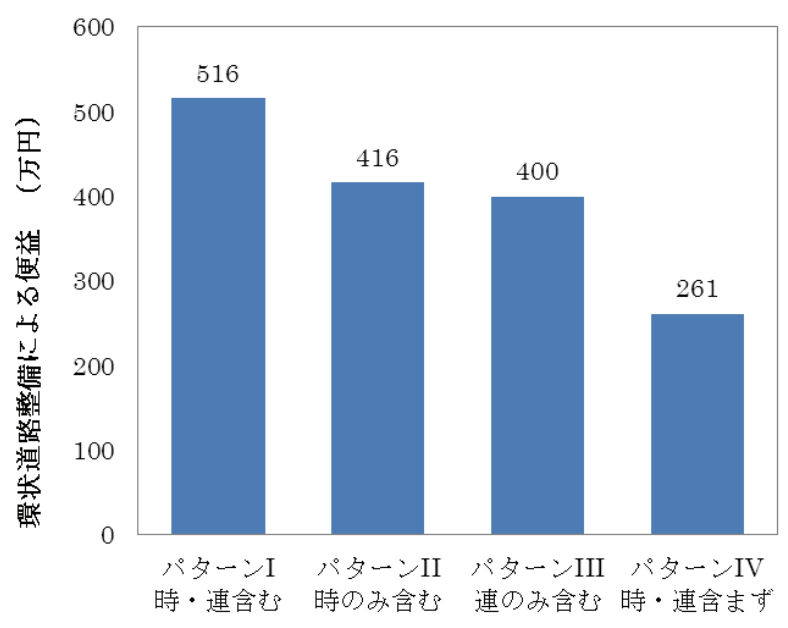

図-5＼cjkstart各パターンにおける便益(万円)

ることができた．また，山側環状道路整備の便益につい て, 連結信頼性や時間信頼性の向上部分も計算可能であ ることを示すことできた.

今後の課題としては, より精密に便益を評価するため の様々な推定が必要である. ネットワークのリンクの途 絶確率の推定方法の確立，金沢市道路ネットワークでの トリップキャンセルコストの推定, 時間信頼性として 何\%タイル值が適切であるのかの決定などである.

\section{参考文献}

1) 中山晶一朗：道路の時間信頼性に関する研究レビュ 一, 土木学会論文集 D3 (土木計画学)，Vol.67, No.1, pp.95-114, 2011.

2) 飯田恭敬, 北村隆一 : 交通工学, オーム社, 東京, 2008.

3) 若林拓史, 飯田恭敬：交通ネットワーク信頼性解析 への信頼性グラフ理論適用の考え方, 土木計画学研 究・講演集, No.10, pp.125-132, 1987.

4) 瀬戸裕美子, 倉内文孝, 宇野伸宏 : 脆弱性の概念を 
用いた道路網接続性評価に関する研究，土木計画学 研究・講演集, Vol.37, CD-ROM, 2007.

5) 星谷勝, 山本欣弥：情報エントロピーを用いたシス テムの信頼性と圥長性の検討, 土木学会論文集, No.654/I-52, pp.355-366, 2000.

6) 中山晶一朗 : ネットワークレベルでの道路交通の信 頼性の諸相・展望とその便益評価の一考察, 土木学 会論文集 D3（土木計画学），Vol.67，No.2，pp.147166, 2011.

7) 今村悠太, 中山晶一朗, 高山純一 : 旅行時間のパー センタイル值に基づく利用者均衡配分モデルによる 信頼性評価法とその金沢市道路ネットワークへの適 用, 土木学会論文集 D3 (土木計画学) , Vol. 67, No. 5, pp. I_625-I_634, 2011.12.

8) 中山晶一朗, 高山純一, 長尾一輝, 所俊宏 : 現実道 路ネットワークの時間信頼性評価のための確率的交 通均衡モデル及びそれを用いた情報提供効果分析, 土木学会論文集 D, Vol. 62, No. 4, pp. 526-536, 2006.

9）田中芳和，村上康紀，井上浩，桑原雅夫，赤羽弘和， 小根山裕之：首都高速道路における OD 交通量の日 変動に関する研究, 交通工学, Vol. 36, pp. 49-58, 2001.
10）北澤俊彦，岩里秦幸，石橋照久, 飛ヶ谷明人：阪神 高速道路における所要時間信頼性評価, 交通工学, Vol.45, No.2, pp.28-35, 2010.

11) 宗像恵子, 割田博：首都高速道路における所要時間 信頼性を考慮した情報提供，交通工学，Vol.45，No.2, pp.22-27, 2010.

12）飯田恭敬，若林拓史：ブール演算を用いた道路網ノ 一ド間信頼度の上・ - 下限值の効率的算出法, 土木学 会論文集，No.395/IV-9，pp.75-84， 1988.

13) 中山晶一朗, 高山純一, 長尾一輝, 笠嶋崇弘 : 旅行 時間の不確実性を考慮した交通ネットワーク均衡モ デル，土木学会論文集，No.772/IV-65, pp.67-77, 2004.10.

14) 中山晶一朗, 高山純一：交通需要と経路選択の確率 変動を考慮した確率的交通ネットワーク均衡モデル, 土木学会論文集 D, Vol.62, No.4, pp.537-547, 2006.11.

15）飯田恭敬, 若林拓史, 福島博 : 道路網信頼性の近似 解析方法の比較研究，土木学会論文集，No.407/IV-11, pp.107-116, 1989.7.

(2013.2. 25 受付)

\section{DEVELOPMENT OF A ROAD APPRAISAL METHOD THAT UNIFIES TRAVEL TIME RELIABILITY AND CONNECTIVITY RELIABILITY}

\section{Satoru TSUCHIKURA, Shoichiro NAKAYAMA and Jun-ichi TAKAYAMA}

The reliability of road networks is becoming more and more important. There are several kinds of road network reliability. So far, the road network reliabilities have not been investigated and evaluated together. In this study, we focus on the travel time reliability and connectivity reliability, which are typically used and popular. We define an expected total cost which includes travel time and connectivity (un)reliabilities, and develop a unified evaluation method of both reliabilities. The traffic stochastic assignment that can assess the two reliabilities is incorporated into the proposed method. Then, the method is applied to Kanazawa road network and its applicability is examined. 